\title{
Dis-soluções textuais na casa dos espelhos modernista
}

Textual Dis-solutions in the Modernist House of Mirrors

Dis-solutions textuelles dans la maison des miroirs du modernisme

\section{Catarina Martins}

\section{OpenEdition}

\section{Journals}

Edição electrónica

URL: http://journals.openedition.org/rccs/924

DOI: $10.4000 /$ rccs.924

ISSN: 2182-7435

\section{Editora}

Centro de Estudos Sociais da Universidade de Coimbra

Edição impressa

Data de publição: 1 Junho 2006

Paginação: 29-40

ISSN: 0254-1106

\section{Refêrencia eletrónica}

Catarina Martins, "Dis-soluções textuais na casa dos espelhos modernista », Revista Crítica de Ciências Sociais [Online], 74 | 2006, colocado online no dia 01 outubro 2012, criado a 01 maio 2019 URL : http://journals.openedition.org/rccs/924 ; DOI : 10.4000/rccs.924 


\section{Dis-soluções textuais na casa dos espelhos modernista}

Um dos aspectos mais relevantes do modernismo, enquanto autocrítica da modernidade, é a tentativa de salvar o sujeito das prefigurações normativas da razão moderna. Trata-se de uma busca identitária que implica a derrocada das construções estabelecidas da realidade e a produção de novas narrativas do todo que preservem o individual. O modernismo representa uma racionalidade estética subversiva e auto-consciente que tende para um modo do discurso e do pensamento que desenha o sujeito na sua relação com o mundo: o ensaio. Na ficção narrativa de expressão alemã do início do século $X X$, a confluência de modernismo e ensaísmo conduziu a híbridos textuais que desafiam uma noção de texto fundamentada na compreensibilidade. Diversos efeitos de espelho articulam a dissolução dos paradigmas epistemológicos e estéticos tradicionais com novas soluções para a escrita ficcional da realidade e do sujeito. A reflexividade ensaística surge no centro da reacção do modernismo à modernidade e da redenção sincera e encenada de um Eu irremediavelmente perdido.

Se, como é sabido, a crítica da modernidade constitui, em grande medida, a motivação e a base do pensamento filosófico de Theodor W. Adorno, o modernismo, entendido como uma autocrítica da modernidade, poderá constituir um ângulo prismático essencial para uma reavaliação crítica da dialéctica do Iluminismo, ao longo de toda a obra do filósofo e, com particular evidência, na Teoria estética, que, fundamentalmente, corresponde a uma teoria da arte modernista. A arte, "antítese social da sociedade", tal como se pode ler logo no início da Teoria estética (Adorno, 2002: 19)1 constitui o fulcro da oposição aos principais discursos da modernidade, nomeadamente à ciência e à filosofia positivistas, bem como às estruturas de poder totalitárias que estes discursos viriam a sustentar. A modernidade inverteu o potencial de emancipação do Iluminismo ao construir uma nova narrativa, reguladora e de pretensões universalistas, que pretendia subsumir o Todo à homogeneidade do objecto, ou da objectividade, anulando, por conseguinte, o heterogéneo, o individual, o sujeito. $\mathrm{O}$ indivíduo e o pensa-

$\overline{1}$ Todas as traduções são minhas. 
mento livres foram relegados para a arte, o único domínio no qual a subjectividade parecia permitir a busca de uma nova identidade e de um novo sentido num mundo de alienação. Contudo, esta busca tornou-se, ela própria, altamente problemática no quadro da modernidade. De facto, a crise de identidade que a maioria dos críticos considera ser central no modernismo, em particular no contexto de expressão alemã do início do século XX, encerrava paradoxos dilemáticos e impossíveis de resolver. Um destes paradoxos é captado de forma expressiva por Adorno, através da personagem lendária do Barão de Münchhausen, que tenta salvar-se a si próprio de morrer afogado num pântano puxando pela trança do próprio cabelo. Em Minima Moralia (1951), Adorno exige ao pensador que se posicione no exterior da temática que está a questionar, ao mesmo tempo que, porém, adopta uma perspectiva interna à mesma (Adorno, 2004: 83). A experiência desta ambivalência é crucial para o modernista, o qual, simultaneamente, é parte integrante (enquanto produto e agente) e oponente da modernidade e do seu paradigma epistemológico racional - um dilema que atinge a expressão máxima com Friedrich Nietzsche, no final do século XIX, e que é indispensável à compreensão da especificidade das questões em torno do sujeito modernista nos espaços culturais de expressão alemã no início do século XX.

Nietzsche usa as armas racionais do Iluminismo para desmantelar as construções modernas da realidade, concluindo que as afirmações racionais da Verdade não passam de ficções, e que esta constatação, fatalmente, abrange o Sujeito. Nietzsche anuncia o crepúsculo do Eu, o Eu cartesiano da modernidade, como apenas mais um ídolo: "E até o Eu! Tornou-se uma fábula, uma ficção, um jogo de palavras: deixou por completo de pensar, de sentir, e de querer!...” (Nietzsche, 2004: 91). A partir do momento em que é posto em funcionamento, o motor crítico do raciocínio livre não se detém perante nada, acabando, no limite, por permitir um único modo de existência: o estético. Tanto a realidade como o sujeito não passam de metáforas, tropos. A linguagem e o texto são a sua única substância, e esta substância é meramente virtual. O pântano de Münchhausen pode ser interpretado como este mundo em desintegração, que absorve o Eu. $\mathrm{Na}$ viragem do século XIX para o século XX, nos países de expressão alemã, os escritores lamentam a "perda do Eu", ${ }^{2}$ fragmentado e sem qualquer centro evi-

\footnotetext{
${ }^{2}$ Sob o título "Das Unrettbare Ich" (1904), Hermann Bahr apresenta um testemunho importante da recepção entusiasta das teorias de Ernst Mach. Em conjunto com as teorias de Freud, o pensamento machiano conduziria a uma crença alargada na definitiva perda de unidade do sujeito, bem como a um profundo sentimento de crise identitária nos meios intelectuais e artísticos dos países de expressão alemã no início do século XX.
} 
denciável. Todavia, estes modernistas estão conscientes de que o sujeito desintegrado depende da encenação voluntária da sua própria redenção, a qual pode, pelo menos de forma ilusória, constituir uma salvação em relação ao desespero, ou ao pântano, niilista. Apesar de atormentado pela lucidez racionalista, ou por este exacto motivo, o artista modernista entra no jogo histriónico do fingimento e do disfarce, postulando-se a si próprio como a instância criativa absoluta, na qual o próprio mundo, redefinido em termos estéticos, tem origem. O Eu modernista cria sucessivas realidades estéticas ou máscaras, a partir das quais consegue construir uma noção de identidade. Esta, porém, é tão precária que não escapa à lucidez crítica que a denuncia, simultaneamente, como mais uma ilusão. Como Fernando Pessoa em Portugal, os modernistas de expressão alemã encaram o fingimento como a única forma de continuar a viver com a razão, e no seio da modernidade. Contudo, de modo a servir o objectivo de sobrevivência, é indispensável que este fingimento seja "sincero", tal como o pessoano. O caminho para atingir esta sinceridade é aliar a máscara a um processo de desmascaramento paralelo e concomitante, ou fundir a ficção com a respectiva ruptura reflexiva, ou seja, reproduzir o dilema interior do sujeito modernista entre a necessidade de encenar uma crença em si próprio e a desconstrução céptica da mesma. Com este fim, os modernistas de expressão alemã intensificam a auto-reflexividade do texto literário, recorrendo aos métodos, à estrutura e ao discurso do ensaio.

É evidente que a arte, tal como é concebida pela tradição idealista, não poderia realizar esta complexa missão. De facto, as reivindicações kantianas de autonomia para o reino estético, fechado em si mesmo como uma subjectiva "finalidade sem fim", e em oposição a um mundo exterior regulado pela racionalidade e pelo pragmatismo utilitarista, não conseguem dar resposta à ideia nietzschiana de uma desintegração global, produto inevitável de um raciocínio crítico (moderno) arrasador, impossível de deter, nem mesmo pelas fronteiras que ele próprio definira, em particular as da arte. Para além disso, a concepção tradicional da obra de arte como uma totalidade harmónica que encerraria um sentido a aguardar revelação contradiz a mundivisão de Nietzsche: uma mundivisão anti-metafísica que recusa a existência de uma Verdade ou Ideia subjacentes à superfície fenomenológica da realidade e que concebe esta última, no seu eterno devir dionisíaco, como a única aproximação a uma noção de "sentido" para o mundo. É interessante notar que Nietzsche, na sua chamada fase aufklärerisch ou iluminista, ou seja, nos seus textos mais racionalmente críticos, acabou por recusar a exclusividade da arte sobre o dionisíaco, estendendo-o, ainda enquanto princípio estético, à realidade como um todo. O significado deste facto para a com- 
preensão do modernismo não deve ser subestimado: a arte não somente deixou de ser considerada como distinta da realidade ou da sociedade, e apenas mais um dos muitos domínios de especialização da modernidade, como passou a ser perspectivada como a consequência lógica (ou racional) da racionalidade moderna. A arte não deve afirmar a subjectividade, o instinto ou o irracional em contraposição à razão, tal como desejava o paradigma moderno, mas abranger todos estes princípios como partes inerentes da dinâmica estética que, afinal, é a lógica própria do real. Desta forma, o estético não só transgrediu, como eliminou as fronteiras que lhe haviam sido atribuídas pela modernidade, tornando-se aplicável globalmente a uma realidade concebida como narrativa ou texto e abrindo novas possibilidades para repensar e reescrever o mundo de uma forma alter-racional ou modernista. Como Nietzsche, os modernistas nunca deixaram de sentir uma nostalgia paradoxal de um sentimento reconfortante de totalidade e unidade, no real como na arte. A solução surge, mais uma vez, através do ensaio.

De facto, o ensaio acaba por se tornar numa reacção münchhausiana à modernidade. Em "Der Essay als Form" ["O ensaio enquanto forma"] (1958), Adorno caracteriza o género como um produto misto, situado entre a filosofia ou a ciência, por um lado, e a arte, por outro. O hibridismo do ensaio revela a função subversiva do género, em termos epistemológicos, políticos e estéticos. Tal como o modernismo, o ensaio recorre ao potencial de emancipação da razão moderna e exerce um raciocínio crítico subjectivo e assistemático, cujos métodos, tais como a ambivalência, a alegoria ou as metáforas, são de natureza fundamentalmente estética. O foco arbitrário do ensaio é a experiência individual e a contingência histórica aniquiladas pelos discursos modernos sob abstracções totalitárias. O ensaio não somente cria uma ruptura e um interstício, no contexto da modernidade, para a emancipação da dissonância que Adorno, inspirado em Schönberg, considerava ser o objectivo do modernismo, como, para além disso, transforma a dissonância, a negatividade e o não-idêntico (na terminologia adorniana) na chave para uma compreensão diferente do todo. Na realidade, a questão central da escrita ensaística é uma questão epistemológica que tem a ver com a possibilidade de pensar a totalidade no seio de uma modernidade cujo paradigma cognitivo destruiu as concepções anteriores do todo, baseadas no mito, na religião e noutras formas de transcendência. A nova totalidade alter-moderna (ou modernista) tem de ser uma totalidade que tenha em conta o elemento insubmisso que não se conforma aos discursos modernos e que revela o carácter ilusório ou falso destes últimos. Através do seu próprio processo de construção, que corresponde a um estatuto permanentemente aberto, o todo modernista deve reflectir a sua "falsidade" inerente 
e criar a consciência de que há uma infinidade de maneiras possíveis de reescrever a mesma narrativa. Isto é conseguido através da criação constante de superfícies reflectoras ou espelhos. O reflexo no espelho, enquanto imagem invertida ou paradoxo de um determinado conceito sob uma determinada perspectiva, é multiplicado em séries infinitas, que permitem a reconstrução do todo como uma casa de espelhos global, ou como uma rede multi-perspectívica, tensa e dinâmica de relações antitéticas (uma série aberta de dialécticas adornianas que rejeitam a síntese). Esta trama ou campo de forças (nas palavras de Adorno) articula o particular numa nova totalidade que, a cada passo, revela o respectivo negativo. É assim que o ensaio concretiza a sua missão de desconstrução, na qual pode fundamentar um precário valor de verdade. É interessante constatar que este processo é muito semelhante ao da construção do sujeito modernista e à sinceridade auto-reflexiva do seu fingimento. De facto, a escrita ensaística, a construção da identidade e as concepções modernistas do mundo e da arte evoluíram numa relação estreita, sendo difícil, senão impossível, dissociá-las.

O criador do ensaio é, evidentemente, Montaigne, no final do século XVI. Os Essais de Montaigne formam uma espécie de mosaico da realidade, composto por reflexões subjectivas sobre uma extensa variedade de temas. Ao mesmo tempo, os esses ensaios vão definindo, gradualmente, os contornos do respectivo sujeito criativo, através das perspectivas sucessivas que este adopta em relação aos fragmentos de um mundo textualmente construído. Apesar do seu cariz diversificado (que se estende do filosófico ao lírico e rompe com todas as formas de convenção discursiva), estes fragmentos são articulados não apenas através do seu eixo comum (o Eu), mas também através de diferentes mecanismos reflexivos e textuais, dos quais se salientam a autocrítica, a intertextualidade e a citação. O resultado é uma correlação interactiva de duas constelações ou campos de forças. A primeira constelação é uma realidade infinita, flutuante, descontínua, paradoxal e tensa, criada por um sujeito através de meios não objectivos. A segunda é um sujeito mascarado, fragmentado, não substancial, e sujeito a revisões e metamorfoses constantes. Os ensaios de Montaigne são uma expressão precoce da crise do sujeito modernista e uma antecipação da respectiva solução precária: o Eu torna-se uma estrutura aberta, dinâmica e cumulativa, que equaciona dialecticamente a identidade enquanto alteridade em relação a tudo o resto, por um lado, com a identidade do sujeito com o mundo como um todo, por outro lado. O texto em si, o ensaio enquanto forma, é central a este processo de construção, porque materializa tanto a realidade quanto o sujeito como narrativas correlativas, constituindo o único espelho ou corpo no qual o sujeito pode rever-se ou sentir-se enquanto unidade, mesmo que 
esta unidade seja aberta e eternamente outra. Montaigne realça com frequência a sua crença na autenticidade deste espelho e na relação sincera que a escrita ensaística estabelece entre o escritor, o texto, e os seus leitores.

Em 1789, um dos principais teorizadores do Romantismo alemão apresenta um conceito semelhante de ensaísmo no famoso fragmento $116 \mathrm{da}$ revista Athenäum. Friedrich Schlegel usa a imagem de "uma interminável fila de espelhos" para descrever a utopia de uma "poesia universal progressiva", que conferiria unidade ao mundo através da única linguagem que lhe é consubstancial: a estética. Esta utopia constitui uma reacção do Romantismo ao Iluminismo racional e normativo e prefigura as propostas de Nietzsche e do modernismo. O livre arbítrio do sujeito criativo torna-se senhor absoluto de uma reescrita estética da realidade que, tal como o ensaio, dissolve as convenções dos géneros e dos discursos, pretendendo integrar gradualmente todas as formas de expressão, a partir do fragmento, central na estética romântica. O novo mundo-texto estético funciona como um espelho do Eu. Em Schlegel, reencontramos a correlação montaigniana entre as reconfigurações do todo e do sujeito. O texto poético imaterial, o tropos de Nietzsche, é a substancialidade possível do Eu e do mundo. Porém, ao contrário de Montaigne, a metáfora schlegeliana do caleidoscópio revela que o romântico já não acredita na possibilidade de um reflexo sincero do sujeito, porque o mecanismo de reflexão num espelho introduz uma distorção, ou um elemento de fingimento, que é ampliado sucessivamente pela fila interminável de espelhos. A dissonância existente dentro do Eu está presente e é desdobrada nos múltiplos espelhos das suas identidades possíveis. O elemento de dúvida que distingue a afirmação "este sou eu" de Montaigne da proposição "este talvez seja eu" (ou um dos meus muitos "eus") de Schlegel traduz a dinâmica experimental da epistemologia e escrita ensaísticas (sublinhada por Adorno). A consciência de que só é possível uma mimese tentativa do sujeito, e a insatisfação consequente, suscitam uma auto-reflexividade intensificada ou o recurso incessante à "ironia romântica" aplicada ao Eu: um movimento espiral contínuo, desencadeado por uma mudança de perspectiva, que denuncia uma revisão autocrítica, não apenas do Eu em si mesmo (se é que ele existe) como de cada uma das suas imagens estéticas possíveis. Por isso, o Eu poético e universal de Schegel é tão complexo, tão uno e tão desintegrado como uma casa de espelhos global, uma teia fantasmagórica de inúmeros fenómenos textuais de refracção e reflexão, tal como a totalidade ensaística de Adorno.

Schlegel e Nietzsche deslocam o ensaio da posição intermédia que ocupava entre a literatura e a filosofia, para a arte. Uma vez que a realidade, tal como a conhecemos, não passa de uma ficção arbitrária, e que o princí- 
pio estético da criação e da criatividade (o dionisíaco) é o seu único sentido, os artistas convertem-se em "activistas" por excelência, cujas obras oferecem reinterpretações e reconstruções do mundo texto que lhes é consubstancial. Este dado é decisivo para os modernistas de expressão alemã, para os quais o ensaísmo, enquanto modo de pensar-escrevendo se torna central na criação de alternativas a uma modernidade particularmente opressiva, urbana, industrializada, imperialista e militarista. A transferência do ensaio para a ficção narrativa permite um raciocínio nicht-ratioïd especulativo e subjectivo, no reino da possibilidade, segundo a proposta de Robert Musil, em O bomem sem qualidades, exemplo paradigmático do romance ensaístico na literatura de expressão alemã. ${ }^{3}$ Em conjunto, o ensaísmo e a ficção revelam uma consciência profunda da realidade e do sujeito como construções estéticas, todas elas ilusórias ou falsas e, por isso, permanentemente carentes de revisão. Acima de tudo, a ficção ensaística torna manifesta uma fractura mais profunda no "Eu irremediavelmente perdido", aquela que torna impossível um posicionamento directo do autor em relação a qualquer aspecto da realidade, como acontecia no ensaísmo "sincero" de Montaigne. $\mathrm{O}$ autor deixou de poder assinar qualquer tipo de afirmações, eventualmente interpretáveis como uma parte da sua identidade. A ficcionalidade suspende toda e qualquer relação directa do texto com o seu sujeito empírico e amplia o jogo histriónico. Contudo, tal como sugeri acima, a salvação do "Eu irremediavelmente perdido" implica um momento de sinceridade no fingimento. Por isso, em vez do espelho unívoco de Montaigne, os modernistas de expressão alemão constroem casas de espelhos schlegelianas altamente complexas: o universo ficcional é preenchido não apenas com múltiplas recriações da realidade e do sujeito, mas também com as respectivas reconfigurações auto-reflexivas, em teias frequentemente inextricáveis. O resultado inevitável é uma "ficcionalidade tensa", na qual o próprio texto cria e fragmenta sucessivos mundos possíveis, e se pressupõe que o leitor respeite o pacto de crença imposto pela ficcionalidade e, em simultâneo, desmascare estes universos como ficcionais ou construídos. Apesar de constituírem um acto de fingimento através da ficção, estas narrativas representam um gesto de profunda sinceridade, porque se expõem, constantemente, como um artefacto, revelando a intenção e os métodos do respectivo criador e desenhando, concomitantemente e como parte do mesmo processo, o retrato deste último. A ficção ensaística é um documento excelente da auto-consciência do artista, frequentemente realçada como típica do modernismo.

\footnotetext{
${ }^{3}$ Nicht-ratioïd é a expressão escolhida por Musil para designar um método cognitivo que funde formas de percepção racionais e não racionais.
} 
Por esta razão, não surpreende o facto de muitos modernistas escolherem o espelho como metáfora central das suas obras.

Tropen [Tróp(ic)os] (1915), o romance principal do expressionista austríaco Robert Müller, é geralmente considerado incompreensível. Esta classificação apressada deve-se à estrutura intencionalmente mistificadora do romance, que induz o leitor, consecutivamente, a acreditar e a duvidar do que lhe é apresentado, quer se trate de afirmações expressas, das personagens e acontecimentos, do universo narrativo, ou da própria realidade, identificada no título do romance como apenas mais um conjunto de tropos nietzschiano. O narrador caracteriza o romance como o resultado de um princípio ensaístico semelhante à "dialéctica negativa" de Adorno:

Aquilo que eu descobri aqui não é mais do que o símbolo do paradoxismo. Alternamos uma coisa, fazemo-la de outra maneira, absurda, invertida, e, vejam, também é alguma coisa. [...] Aprendam a escandir as realidades! Igualdade de direitos para o paradoxo. O paradoxo abre novos mundos, dá sorte, alarga as possibilidades... [...] Eu proclamo o espelho, a inversão, o paradoxo! (Müller, 1993: 55-7)

A concepção da realidade como um texto estético que pode ser reescrito em infinitas constelações novas (todas elas com um igual valor de verdade ou falsidade), e a ideia de que todas as proposições podem ser invertidas, fazem parte de uma estética modernista que renuncia a transmitir uma mensagem, por oposição à obra de arte da tradição clássico-idealista, e se entrega ao jogo da auto-reflexão experimental interminável e (romanticamente) irónica - uma aventura com tão pouco sentido como a malograda caça ao tesouro que constitui a intriga nuclear do romance. Em Tropen, encontramos um reflexo invertido ou uma antítese (mas nunca uma síntese) de tudo, das sequências narrativas mais extensas à expressão mais diminuta, incluindo categorias narrativas, tais como as personagens, o tempo ou o espaço, os quais podem ser interpretados, simultaneamente, como os elementos clássicos da ficção narrativa e como representações simbólicas ou visuais de argumentos ensaísticos. O processo de mascarar/desmascarar é tão coerente que chega a oferecer reflexos para os reflexos precedentes. Este efeito é conseguido, em parte, através do uso intensivo dos métodos auto-reflexivos do próprio modo narrativo, como a multiplicação de níveis narrativos encaixados, a alteração constante da perspectiva narrativa, a mise-en-abyme, e a criação de múltiplos alter-egos para cada personagem, para além de recursos tipicamente literários, como a alegoria ou as cadeias de leitmotive, e a auto-citação. É interessante, sobretudo, a forma como o narrador e as personagens explicam o sentido e o objectivo do romance, 
e o revêem ironicamente inúmeras vezes. O leitor fica perdido no meio de vozes que provêm do universo ficcional, mas exprimem ideias que o transcendem e que só podem ser do autor. A partir do interior do mundo romanesco, Müller desenvolve um ensaísmo engenhoso que mina o "sentido" e a credibilidade daquele enquanto ficção e realça, de forma constante, o papel dialéctico do autor como o criador e, simultaneamente, o receptor mais crítico da sua própria obra. Elementos tão variados como a psicologia do autor ou a evolução das suas concepções estéticas e epistemológicas são revelados através do processo criativo contínuo espelhado no texto narrativo. Trata-se, afinal, de um processo de auto-descoberta no labirinto amazónico da modernidade em desagregação. O resultado é um caleidoscópio incompreensível, centrado, tal como a teoria de Schlegel, na dualidade entre ficção e realidade: as certezas da modernidade e a possibilidade de percepção do real e do sujeito são negadas através da respectiva dissolução numa selva de espelhos irreal e mística. Composto por infinitas ramificações, o romance só pode ser apreendido como um todo que não encerra nenhuma mensagem, mas que, certamente, provoca um efeito intenso sobre o leitor: o efeito da incompreensibilidade, de ser atirado de um lado para o outro por um redemoinho, semelhante ao delírio febril das personagens do romance, atingidas pela malária e incapazes de distinguir o pesadelo da realidade, ou o seu Eu em relação às restantes personagens ou à natureza envolvente. Na sua materialidade como constelação visual e na dinâmica de campo de forças do seu jogo paradoxal e relativista, Tropen constitui um retrato fiel do dilema münchhausiano do modernista, que Müller acredita ser potenciado pelo facto de o Barão puxar uma trança, não do seu próprio cabelo, mas de uma peruca, uma espécie de máscara (Müller, 1995: 93): a encenação sincera da desintegração e redenção dialécticas do todo e do Eu através do texto estético e pela mão desesperada, mas narcisistamente autoritária, do sujeito criador. Embora virtual como um tropos, o texto é também o corpo mais palpável do sujeito modernista e a sua única (dis-) solução.

As dis-soluções textuais ensaísticas podem ir mais longe do que o exemplo anterior: nalguns textos, o nível de hibridismo entre a ficção e o ensaio é tal que desaparecem quase na totalidade os fragmentos de uma e do outro. Um exemplo notável é a obra Bebuquin oder die Dilettanten des Wunders [Bebuquin ou os diletantes do maravilhoso] (1906-7) do expressionista alemão Carl Einstein, na qual o espelho é, mais uma vez, a metáfora central e unificadora. Neste texto impossível de classificar em termos genológicos, composto por 19 fragmentos extremamente soltos e díspares, uma personagem representa o espírito relativista e multi-perspectivista da reflexão 
ensaística. A sua cabeça é um poliedro composto por inúmeras superfícies reflectoras, através das quais a personagem transfigura a realidade material numa fantasmagoria ironicamente mais real. Esta personagem funciona, assim, como um espelho interno, uma espécie de mise-en-abyme, da própria dissolução do texto narrativo em Bebuquin, que, paradoxalmente, forma uma nova unidade modernista da obra de arte: uma unidade da dissonância, por oposição à unidade harmoniosa da estética clássico-idealista. Para ser capaz de formular o "sentido" deste texto, o leitor é forçado a apreendê-lo como uma teia, indivisível mas tensa, de relações, discursos e mecanismos semióticos extremamente diversos. Bebuquin exige uma leitura combinada e articulada da narrativa e da reflexão ensaística. A acção é mínima e descontínua, e a sua progressão é transferida para um raciocínio labiríntico, cujos pilares são as frases desconexas proferidas por uma espécie de personagens simbólicas, e os seus diálogos absurdos, feitos de misturas incompreensíveis de discursos e citações abstractas, que criam efeitos grotescos. O tempo e o espaço desfazem-se, enquanto categorias narrativas: o primeiro só pode ser apreendido como "tempo da recepção", ou o tempo que o leitor demora a reconstruir pelo menos algumas das complexas e desviantes sequências de eventos e de raciocínios, adquirindo assim a ilusão de ter "lido" o texto; o segundo, que inclui locais como uma feira, um circo e um cabaret significativamente chamado "Essay" ["Ensaio"], funciona meramente como uma evocação simbólica do "maravilhoso" como o negativo da razão moderna. O narrador está presente apenas de forma intermitente e é altamente metamórfico; o processo de narração é decomposto em inúmeras perspectivas e realizado por vozes não identificáveis, o que tem como consequência a denúncia da presença constante do autor como responsável por um texto que se apresenta intencionalmente como construção. As únicas referências precárias para uma formulação vaga e interrogativa do "assunto" do texto são uma espécie de instruções de leitura, dispersas ao longo da obra e com variações ao jeito de leitmotive. Estas instruções, porém, são contraditas ou tornadas absurdas, mais uma vez, através de uma rede de reflexos invertidos ou deformados, criados pelos múltiplos mecanismos de choque ao nível da linguagem, do discurso, e até da própria estrutura textual, ou através do uso irónico e grotesco das personagens, do espaço, dos ambientes, e dos acontecimentos. No último episódio, uma coluna de espelhos deformantes funciona como um cataclismo social tão poderoso quanto a razão dionisíaca de Nietzsche. Mais uma vez, o resultado é o caos, o efeito de redemoinho do texto como um todo, desta feita evidenciado por um espelho alegórico interno. O texto recusa um "sentido" e afirma como única legitimação a sua função crítica demolidora: uma busca ensaística de 
uma forma de existir com e para além da razão, cujas consequências são, exclusivamente, o material estético incompreensível e o seu efeito arrasador de desespero.

Apesar de profundamente reflectida e de meticulosamente construída, isto é, artificial ou fingida, esta é a máscara mais sincera do sujeito e da arte modernistas. A expressão fiel da concepção modernista do Eu e da realidade como um todo é o texto literário ensaísta que oscila entre a dissolução e a resolução auto-reflexivas, o texto que, como o mundo moderno e o eu modernista fragmentado, tanto impõe como recusa a redenção hermenêutica (racional) do sentido. Tal como Adorno observa, na sua Ästhetische Theorie, a respeito do modernismo, "[a]s obras de arte não devem ser compreendidas pela estética como objectos hermenêuticos. O que devia ser compreendido, no estado presente, é a sua incompreensibilidade" (Adorno: 2002: 179).

\section{Referências bibliográficas}

Adorno, Theodor W. (1975), "Der Essay als Form", in Th. Adorno, Noten zur Literatur I. Frankfurt a.M.: Suhrkamp, 9-49.

Adorno, Theodor W. (2002), Ästhetische Theorie. Frankfurt a.M.: Suhrkamp.

Adorno, Theodor W. (2004), Minima Moralia. Reflexionen aus dem beschädigten Leben. Frankfurt a.M.: Suhrkamp.

Adorno, Theodor W.; Horkheimer, Max (2003), Dialektik der Aufklärung. Philosophische Fragmente, Frankfurt a.M., Fischer;

Bahr, Hermann (1982), "Das unrettbare Ich”, in Gotthart Wunberg (org.), Die Wiener Moderne. Literatur, Kunst und Musik zwischen 1890 und 1910. Stuttgart: Reclam, 147-148.

Einstein, Carl (1994), Bebuquin oder Die Dilettanten des Wunders“, in C. Einstein, Werke. Berliner Ausgabe. Band I 1907-1918. Berlin: Fannei \& Walz.

Montaigne, Michel de (1972), Essais. Tome I-III. Org. Pierre Michel. Paris : Le Livre de Poche.

Müller, Robert (1993), Tropen. Der Mythos der Reise. Urkunden eines deutschen Ingenieurs. Org. Günter Helmes. Stuttgart: Reclam.

Müller, Robert (1995), "Macht. Psychopolitische Grundlagen des gegenwärtigen Atlantischen Krieges", in R. Müller, Gesammelte Essays. Org. Michael Matthias Schardt. Paderborn: Igel Verlag, 85-140.

Musil, Robert (1981), Gesammelte Werke 8. Essays und Reden. Org. Adolf Frisé. Reinbek bei Hamburg: Rowohlt.

Musil, Robert (1999), Der Mann ohne Eigenschaften I. Erstes und zweites Buch. Reinbek bei Hamburg: Rowohlt. 
Nietzsche, Friedrich (2004), Der Fall Wagner. Götzen-Dämmerung. Der Antichrist. Ecce homo. Dionysos-Dithyramben. Nietzsche contra Wagner. Org. Giorgio Colli/Mazzino Montinari. München: dtv.

Schlegel, Friedrich (1967), "Progressive Universalpoesie”, in F. Schlegel, Kritische Ausgabe seiner Werke. Vol. II, Charakteristiken und Kritiken, I (1796-1801). Org. Hans Eichner. München, Paderborn, Wien: Schöningh, 182-83. 